\title{
INHERENT IMPROPRIETIES IN THE INCOME TAX AMENDMENT TO THE FED- ERAL CONSTITUTION
}

This may seem a rather formidable and imposing title to some readers. But I simply wish to convey the idea that there are certain fundamental improprieties, inconsistent with our Republican institutions and with the dual form of our government, which render an adoption of the income tax amendment to the federal Constitution a serious innovation. Constitutional, of course, it will be because everything is constitutional which that instrument permits; but such an amendment will certainly involve a grave impropriety.

It is purposed to change the United States Constitution by adding thereto the following, as the sixteenth amendment, which shall read:

"Congress shall have power to lay and collect taxes on incomes, from whatever source derived, without apportionment among the several States or without regard to any census or enumeration."

The federal government now has power to tax incomes; but as the Supreme Court has construed that clause of section 8 of the Constitution, which reads: "No capitation or other direct tax shall be laid unless in proportion to the census or enumeration hereinbefore directed to be taken," to include an income tax; therefore, it follows that the general government can now collect such a tax only by apportioning the amount of the same among the several states according to population.

I apprehend that to the majority of the people of this country the question as to whether the federal government should adopt the income tax is largely an economic and practical one. The fundamental legal aspects have not received serious enough consideration. If the income tax is economically wise and sound, and if it is practicable to collect it, equitably and honestly, from the persons on whom it is imposed, probably the majority will reply, assuredly the general government at Washington should have this power to levy and collect an income tax throughout the country. But quite apart from the wisdom and soundness of such a $\operatorname{tax}$ in theory, owing to the peculiar nature of our institutions, and judging from the limitations with which the powers of the 
general government have been surrounded, the nation's founders who framed that matchless code of law, the United States Constitution, never intended that the federal government should exercise the unqualified power to levy an income tax. We should be careful to distinguish at the outset between an income tax inposed by the State government and such a tax levied by the general government at Washington. As to the former there can be no objection or criticism whatever, so far as the constitutional proprieties are concerned; but it is against the latter that the limitations of a government of enumerated powers so seriously militate.

THE SUPREME COURT AND THE INCOME TAX.

It is quite unnecessary for us to discuss at length the question whether the income tax is a direct tax. That question can no longer be considered open. It was solemnly adjudicated in the famous case of Pollock $v$. Farmers' Loan and Trust Company in 1895 , and, of course, the very proposal of an amendment to the United States Constitution, giving Congress power to impose an income tax without apportionment is itself an admission that the term "direct taxes" includes an income tax. But, on the other hand, owing to the fact that the Supreme Court has been, by some, seriously criticised in its decision, it is well and proper to devote some consideration to that question. Indeed, a part of the agitation in favor of an amendment to the Constitution grows out of the charge that the Supreme Court, in deciding the Pollock case, "changed its mind" (so the critics say), reversed all prior decisions and erred in its judgment. That the Supreme Court reversed a prior judgment must be admitted, but the remainder of the charge against this high tribunal is wholly without justice. It may be briefly said that, as one reacls to-day the arguments of the learned counsel and the opinions of the justices in that case, freed from the disappointment which influenced some

${ }^{1}$ I57 U. S., 429 ; affirmed on rehearing before a full bench, 158 U. S., 565 (four justices dissenting, but only on the point of income derived from personal property.) It is very plain as one reads through the elaborate dissenting opinions of Justices White and Harlan in the Pollock case that the main basis for their judgment is the principle of stare decisis. On the same principle, also, are based the expressions of opinion of some of our jurists and constitutional writers, such as Kent, Story, Pomeroy and Ordronaux. The restrictive definition which they give to the term "direct tax" is based almost exclusively on the unfortunate dicta of the justices in the Hylton case. 
minds at the time, there never ought to have been any question, it would seem, as to whether a general income tax is a direct tax.

An earlier case in which the Supreme Court decided flatly that a tax against the citizen in respect of his general income, was an indirect tax, is Springer $v$. United States." The Supreme Court in this case was led into the error of declaring that an income tax was not a direct tax because influenced by the dicta and expressions of opinion of the justices in the very early case of Hylton v. United States. ${ }^{3}$ A great deal of error and misunderstanding has surrounded the actual adjudication of the court in the Hylton case which was confined solely to the point that a tax on carriages of the nature provided for in that act was an indirect tax. That case did not involve any adjudication as to the nature of an income tax.4 It may be that the carriage tax in the Hylton case was an indirect tax, because it was a tax upon consumption, and in its ultimate incidence fell upon the consumer or user of the carriage, and not necessarily upon the owner. In the case of Pacific Insurance Company $v$. Soule ${ }^{5}$ the tax was levied against the income of insurance companies derived in part from premiums on policies; manifestly, this was also an indirect tax because it fell ultimately, not upon the insurance company, but upon the policyholder, whose premium was proportionately increased by the amount of the tax levied. It would seem, therefore, that in its earlier adjudications, the Supreme Court erred in failing to distinguish between the different kinds of income

2 102 U. S., 586.

${ }^{3} 3$ Dallas, I7I. The expressions of personal opinion by Justices Chase and Paterson in the Hylton case, though erroneously followed by the Supreme Court in subsequent years, are not in accord with Hamilton's opinion as expressed in his brief in behalf of the United States in that case, and he must be regarded as perhaps the most eminent authority on the subject at that time. See Works of Hamilton, Vol. VII, 845. In this connection see George Ticknor Curtis in "Revenue Powers of the United States," Harper's New Monthly Magazine, Vol. XXXIII, 354, 362.

\& For example, see the inaccuracy and confusion of language employed by Senator Root in his open letter to Hon. F. M. Davenport, member of the New York State Senate, advocating the proposed amendment, published in Congressional Record, March I, rgro, Vol. XLV, 2564. Governor Fort's message to the New Jersey Legislature of February 16, Igro, on the Income Tax contains a very palpable error on this point. See also the glaring misstatement in Senator Brown's article in the Outlook of January 22, Igro, Vol. 94, No. 4, entitled "The Income Tax Amendment."

${ }^{5} 7$ Wall., 433 
taxes. Practically, it is not every kind of income tax which is a direct tax. The term "income tax" has been too generally and broadly used to cover a variety of taxes imposed on persons and property which may ultimately be payable out of income. There are several instances of taxes of this nature seen in the fiscal history of our own colonies, and of France and England, in which the tax levied really against the property itself has been made payable out of the income, or the amount of the assessment has been measured by the income, and such a tax has been erroneously denominated an income tax. Other illustrations are, perhaps, the "faculty tax" and the partial tax on profits of old colonial days. ${ }^{6}$ Some of the taxes imposed under the internal revenue provisions of our Civil War, while payable out of income or revenue, were not properly income taxes, as, for instance, the tax on premium receipts of insurance companies, and possibly that on bank profits and undivided surplus. But the income tax levied against the general income of the citizen is of a very different nature. It is distinctly a personal tax and undoubtedly a direct tax; in fact, it is difficult to conceive of a tax more direct or personal in its nature than the general income tax. ${ }^{7}$

It may be said in defense of the earlier decisions of the Supreme Court, regarding income taxes, that as the question is not at all a simple one, but surrounded with a great many economic perplexities, the failure to distinguish between the general income tax levied against the person and an excise tax levied against specific sources of revenue, or against property or business, but payable out of income, is not surprising. Very likely it required just such an important case, involving the imposition of a general income tax, fraught with great consequences and freed from the influences and emotions of the Civil War, as was

- See Prof. Edwin R. A. Seligman's article in Political Science Quarterly, Vol X, 22I. "By an income tax we mean a tax upon the personal income of the individual. It is a personal tax, not a tax on things, not a real tax. * * * The new and more general taxes" (on a person's income) "are direct income taxes, and have the characteristics of a personal, not a real, tax." pp. 244 and 246 , Pol. Sci. Quar., X. But popularly, I apprehend that the "faculty tax" of the Colonies was regarded by the men of that day as much a direct tax as a general income tax was.

"See "Theory and Practice of Taxation," by David A. Wells, LL. D., (New York, 1900), pp. 547, 548. "Revenue Powers of the United States," Harper's Magazine, Vol. XXXIII, pp. 354, 355, by George Ticknor Curtis. See, also, brief of counsel for the plaintiff in Pacific Iisurance Co. v. Soule, 7 Wall., 433 . 
presented in Pollock v. Farmers Loan and Trust Company, with its learned and exhaustive arguments and opinions, to give to the country the eminently just decision that the personal income tax is a direct tax. ${ }^{8}$ Instead of subjecting the Supreme Court to criticism, this decision in the Pollock case must ever be taken as the most assuring evidence that the Supreme Court of the United States, though it may at times, unintentionally and in error, wander from the safeguards of true constitutional construction, will sooner or later return to the judicial truth and declare to the American people what are the fundamental principles in our republican government, which have preserved for one hundred and twenty years the remarkable institutions in which every American has so much pride.

It is very interesting to notice in this connection that George Ticknor Curtis, who became one of our foremost American jurists, writing in 1866 , many years prior even to the institution of the Springer suit, declared that the personal income tax was undoubtedly a direct tax and ought to be levied by apportionment among the several States. He had the courage to suggest that the personal income tax of the Civil War was unconstitutional and the revenue therefrom illegally collected. In a most carefully prepared article ${ }^{0}$ he reviewed the question of what were direct taxes from the point of view of judicial construction $;^{10}$ of congressional construction as judged from contemporaneous legislation; of the intent of those who framed and ratified the Constitution, and of a correct constitutional interpretation on the principle of the thing itself. He came to the conclusion that

8 The Pollock case must be counted as one of the most remarkable cases that has yet come before the Supreme Court in its history. Perhaps no case was ever so exhaustively and elaborately argued. The briefs of the counsel were very voluminous and amounted almost to treatises on the subject of taxation, dealing with it from its historical, economic, constitutional and judicial aspects. Pertinent to our discussion here, see particularly the brief of $\mathrm{Mr}$. Clarence A. Seward against the constitutionality of the tax, in which he covered certain features of our political history never before fully understood. In this brief he received the assistance of no less an authority than Prof..Edwin R. A. Seligman, one of the leading political economists of this country.

"Revenue Powers of the United States," in Harper's New Monthly Magazine, Vol. XXXIII, 354 (Aug., I866).

${ }^{10}$ See Mr. Curtis' analysis of the decision in the carriage tax case (3 Dallas, 17I) and the distinction between direct and indirect taxes explained there. 
there should be no question that the founders of our government, in using the expression "direct taxes" meant to include the income tax. In the same article, revealing great confidence in the integrity and wisdom of our highest tribunal and with a judicial foresight that amounted almost to prescience, he declared that signs were not wanting to show that the time would come when the supremacy of the Constitution would be reasserted and the Supreme Court would rightfully adjudge as to the nature of the income tax. After witnessing some adverse decisions, the learned jurist, had he lived, ${ }^{11}$ would have waited thirty years before the Supreme Court, in Pollock v. Farmers' Loan and Trust Company, declared that a general income tax levied without apportionment among the several States was unconstitutional and void.

\section{RESTRAINTS IMPOSED UPON DIRECT TAXES BY THE CONSTITUTIONAL CONVENTION.}

We have now seen that, under the natural and logical signifcance of the term, and by the understanding of those who both framed and ratified the Constitution, a general income tax falls within the expression "direct taxes," and this has been affirmed by the judicial declaration of the Supreme Court of the United States. How does it come that this rule of apportionment is in our Constituion? Has it a natural and rightful place there? Is it a provision which deserves to be respected and now followed?

It has been said that the provision regarding the apportionment of direct taxes was inserted in the Constitution in the midst of a heated debate as a compromise between the conflicting interests of the North and the South. ${ }^{12}$ This is a mistake. Of all the provisions of the Constitution, whether in the nature of com-

II Mr. Curtis died only one year before the Pollock case was decided.

12 Judge Story seems to suggest this in his treatise on the Constitution. I Story, 705, sect. 936. But never until recent years has this theory been seriously contended for. Prof. Chas. J. Bullock must be taken as the leading exponent of this theory of the origin of the direct tax clause. In an article in the Political Science Quarterly he goes at great length into the proceedings of the constitutional convention and elaborately argues that the clause was a mere compromise between the North and the South. Prof. Bullock's article, however, contains many inaccuracies and his conclusions do not follow upon the facts even as he states them, according to all correct principles of logic. "The Origin of the Direct Tax Clause of the Federal Constitution," Political Sci. Quar., Vol. XV, $217,452$. 
promises to adjust the interests of clifferent sections or States, or whether in the nature of a solemn grant to the Union, there are few which more deserve the sanction and respect of the American people than the qualification of the direct taxing power.

Edmund Randolph, of Virginia, in his series of propositions presented to the convention May 29, I787, setting forth the scheme of a national government proposed as his second resolution:

"Resolved, therefore, that the rights of suffrage in the national legislature ought to be proportioned to the number of contribittions or to the number of inhabitants." ${ }^{13}$

Here, before the convention has been in session five days, is the first appearance of the principle that representation and taxation ought to bear some relation or fixed ratio to each other. Mr. Patterson, of New Jersey, set forth the federal idea of government, and his resolutions, submitted to the convention, provided that the general government should not have the power of laying direct taxes until it had first levied its requisitions among the several States and they had failed to fulfill the same. It would seem, therefore, that under either form of government, national or federal, some positive restriction or qualification in the exercise of the direct taxing power was deemed desirable by both parties. At the same time it is significant to note that Charles Pinckney submitted a plan of a constitution which he himself had drawn up containing this provision:

"The proportion of direct taxation shall be regulated by the whole number of inhabitants of every description," etc.

On May 3 oth the convention went into the committee of the whole, and agreed to nineteen different propositions founded on $\mathrm{Mr}$. Randolph's resolutions, which were to be the basis of the new government and which were reported on June 19 th. ${ }^{14}$ These propositions did not contain the resolution fixing the proportion of direct taxes, which was for the time being postponed, but not because of any opposition to the principle itself. ${ }^{15}$ In the com-

$13 \mathrm{~V}$ Elliot's Debates, 126, 127, I28 and I29. Curtis' History of the Constitution of the U. S., Vol. II, Ch. VI, II6-I28.

$14 \mathrm{~V}$ Elliot, I32.

${ }^{16}$ It was objected to more on account of the ambiguity of expression and the possible unwisdom of fixing a restraint different from what had obtained under the Articles of Confeceration, and before the plan of the new government had been definitely fixed. V Elliot, 134, 135. Curtis' Const. Hist. of the U. S. (I889), Vol. I, 334, 335 . 
mittee of the whole it had been agreed that the basis of representation in both branches of the legislature should be according to population and the right of suffrage should be by numbers. But this plan naturally displeased the advocates of the federal style of government and the smaller States; and there then followed one of the most heated struggles of the convention, and which was not determined until July and by the appointment of a committee of compromise ${ }^{16}$ to which the entire question was referred.

This committee reported on July $5^{\text {th }}$ the resolution which formed the first grand compromise of the convention. ${ }^{17}$ It was that each State should have an equal vote in the second branch in the legislature, $i$. e., the Senate; and as a concession to the larger States, it proposed that all revenue measures should originate in the popular branch of the legislature. The committee's report also contained the proposition that slaves should be counted in the ratio of three-fifths to free inhabitants, which subsequently became the basis of the grand compromise between the free and the slave States. ${ }^{18}$ Gouverneur Morris contended that property was as much the object of protection by society as life, and that wealth ought to be represented in the national legislature. This view found support in a number of the members of the convention, among whom were Elbridge Gerry, Rufus King, Gorham and Butler. ${ }^{10}$ Mr. Rutledge declared that the suffrage of the several States ought to be regulated in proportion to the sums paid to the general revenue by the inhabitants of the several States. ${ }^{20}$ Here we find in the propositions of either Morris or Rutledge, the same fundamental principle of American government, whose justice, it seems, was never objected to by a single member of that convention-that the power to impose taxes ought not to be committed to a majority of mere members with

16 See particularly debates of June $25,27-30$, and July 2 ; V Elliot, 238, 239, 240, 249-273 inc. Curtis, Const. Hist., Vol. I, 338, 339, 342346 inc.

17 Curtis' Const. Hist., Vol. I, 406, 407. V. Elliot, 274.

${ }^{18} \mathrm{~V}$ Elliot, 274-278 inc.; 280, 285, 298, 299. Curtis' Const. Hist. I, 409, 410.

$10 \mathrm{~V}$ Elliot, 279, 280, 28r, $29 \mathrm{r}$.

$20 \mathrm{~V}$ Elliot, 279. 
no safeguards for its exercise, ${ }^{21}$ making possible the imposition of burdens on a certain portion of the community to the exclusion of the remainder. The discussion which took place during these days in July in the convention shows that "those patriotic men well knew that the unrestrained and unregulated power of taxation had been, in all the experience of the world, the chief instrument of oppression and tyranny, and while the power was indispensable to the existence of the nation, it was not the less necessary that it should be kept within definite bounds." 22

The question of basing representation on a combined estimate of population and wealth was finally referred to a committee of five, which reported substantially on July gth that the representation in the lower house should be distributed among the States according to a compound ratio of wealth and numbers of inhabitants. This proposition was, for the time being, adopted..$^{23}$ It was at this juncture that the question of slavery first appeared in any way to bear upon the question of the relation of representation to taxation, for it soon became manifest that representation based on wealth had some very impracticable features and particularly opened a wide door to irregularity and fraud in the counting of slaves, which might at one time be counted as property and at another as persons. Some members, too, contended that population itself was the best index of wealth. ${ }^{24}$ On July Ioth and IIth there occurred the most heated debate over the question of representation of slaves, which was finally settled by the adoption of the proposition that three-fifths of the slaves should be counted as free white. Subsequent to this Mr. Williamson's resolution basing representation on wealth and population was rejected. ${ }^{25}$ This seems to have been the last thing that occurred on July IIth, and the next day Gouverneur Morris came forward immediately with his proposition that taxation shall be

21 That the institution of slavery certainly complicated the application of the rule regulating taxation by representation, cannot be denied. But that this principle did not have its origin in an attempt to make a compromise between the North and the South, or was not adopted as a part of the Constitution for that reason, is most apparent. See Curtis' Const. Hist. I, 415,416 . Read the Debates as reported by Elliot, V, pp. cited supra.

22 Former Senator George F. Edmunds in "Salutary Results of the Income Tax Decision," The Forum (I895), Vol. XIX, 513, 516.

$23 \mathrm{~V}$ Elliot, 288.

24 Especially Roger Sherman of Connecticut, V Elliot, 297.

${ }^{25}$ Curtis' Const. Hist. I, 418. 
in proportion to representation..$^{26}$ This resolution, though put in the reverse form by $\mathrm{Mr}$. Wilson, was finally adopted by the convention on July $I 3^{\text {th, }}$ after a long debate, in the following words: "Provided always that the representation ought to be proportional to direct taxation." $2 \pi$

From the debates and the discussions which took place in the convention there is nothing to show that this was first suggested as a compromise on the slave question. It was introduced on July I2th, to take the place of the proposition that representation be based on wealth as well as numbers, which itself had been discarded as being too vague. ${ }^{28}$ The only way in which the institution of slavery affected this question was that the presence of the slaves in the Southern States rendered more apparent the difficulties and objections of basing representation on both wealth and numbers. The crucial point of the compromise on the slave question was the proposition that three-fifths of the slaves should be counted as free inhabitants. ${ }^{29}$ It was around that proposition that all the heated discussions between the advocates of the North and the South centered. Evidence seems conclusive that had there been no dispute on the question of slavery and the South's representation in the House, nevertheless the convention would have adopted, in some form or another, a definite restriction on the exercise of the direct taxing power. ${ }^{30}$

\footnotetext{
$26 \mathrm{~V}$ Elliot, 302.

$27 \mathrm{~V}$ Elliot, 305, 306.

${ }^{28}$ This is manifestly George Ticknor Curtis' view of the matter. Curtis' Const. Hist. I, 4I2, 4I3.

29 Mr. Pinckney's defense in the South Carolina convention, of the clause regulating the basis of representation in the House of Representatives shows clearly that the gist of the compromise between the North and the South was the provision relating to the manner of counting slaves as three-fifths of free inhabitants. V Elliot.

30 Very few constitutional writers of this country have gone into a careful historical analysis of the compromises of the constitutional convention and of the provisions of the instrument itself. George Ticknor Curtis must be taken as one of the greatest authorities in this country on this subject. See Curtis' Hist. of the Const. of U. S. ( 1858,2 Vols.). See also his Const. Hist. of U.S. (N. Y., I889, 2 Vols.). A review of his works will show that he sustains the views expressed above. I do not know of a single writer who, after having made a careful analysis of the proceedings of the constitutional convention, holds to the theory that the qualification of the direct taxing power was inserted as a mere compromise between the North and the South.
} 
In the report of the committee of detail on August 6th the clause in question was submitted in not very different words. Subsequently when the Constitution was finally drafted by the committee of revision in September, the rule concerning direct taxes was placed in the article prescribing the basis of representation, where it naturally belonged, and was made to read as follows:

"Representatives and direct taxes shall be apportioned among the several States which may be included in this Union, according to their respective numbers," etc.

In this form it passed the convention and has since remained a part of the organic law of our government.

The qualification of direct taxes is the only provision in the entire Constitution which appears twice in that instrument. This fact ought to teach us to hold it in still higher regard and to respect the more the earnestness and intent of the framers who placed it there. The second place in which it appears in the instrument is in Section 9, where it appears as a positive restriction upon the legislative powers of Congress in the words quoted on the first page of this article. ${ }^{31}$ The committee of detail on August 6th reported the positive restriction that "no capitation tax shall be laid unless in proportion to the census," etc. But on September I4th, when the convention was going over the Constitution for the last time, Mr. Read, of Delaware, moved to insert after the word "capitation" the words "or other direct tax," and it was immediately agreed to. ${ }^{32}$

THE INCOME TAX UNDER AMERICAN INSTITUTIONS.

When we come to follow the new Constitution out of the Philadelphia convention, and before the people and into the conventions of the several States, the evidence as to the origin and intent of the direct tax clause becomes all the more clear and convincing.

31 The appearance of this restriction on the exercise of the direct taxing power for a second time in the Constitution and among the express prohibitions imposed upon Congress, is the most convincing proof of the intent of the framers, and that they did not regard it as forming a mere compromise between the North and the South. Prof. Bullock in his article in the Political Science Quarterly seems to admit that the second inclusion of this clause in the Constitution is at variance with his theory of a compromise, for he says, "It seems strange that such a clause should have been deemed necessary."

32 Elliot, V, 379, 545. 
It was interpreted by the people as a limitation upon Congress in the exercise of the direct taxing power, to protect them and their property from discrimination and oppression; and by the States it was accepted as a safeguard to their sovereignty and existence. Even such ardent Nationalists as Hamilton and Madison, who did not approve of this provision when it first came up in the constitutional convention, were only too glad to defend the rule of apportionment as an express limitation guarding and confining the imposition of direct taxes.

Thus we find Mr. Hamilton writing in the Federalist in 1788 , prior to the New York convention, and commending the rule as follows: ${ }^{33}$

"Let it be recollected that the proportion of these taxes is not to be left to the discretion of the national legislature: an actual census or enumeration of the people must furnish the rule; a circumstance which effectually shuts the door to partiality or oppression. The abuse of this power of taxation seems to have been provided against with guarded circumspection."

In the Massachusetts convention we find Rufus King, at the very outset, declaring that "It is a principle of this Constitution that representation and taxation should go hand in hand. And it was adopted because it was the language of all America." Can any words be plainer? Is there anything here savoring of a sectional or temporary compromise?

Patrick Henry, the old Revolutionary patriot and orator, declared with earnestness in the Virginia convention: "I will not give up the power of direct taxation but for a scourge." 35 We are not used to such impassioned oratory in these days, but it was not uncommon then, and let no reader belittle the popularity and strength of the views of Patrick Henry. He was a sincere patriot and had behind him all but a majority of that Virginia convention ready to vote down the proposed Constitution. While ninety millions of people must now rejoice that Mr. Henry's position did not prevail, let no one of them mistake that were it not for the qualification restricting the exercise of the direct taxing power, the Constitution would never have been ratified by Virginia, New York, New Hampshire, ${ }^{38}$ South Carolina, Massa-

${ }^{33}$ The Federalist (Lippincott, Philadelphia, I888), No. XXXVI, p. 276.

34 II Elliot's Debates, 36.

85 III Elliot's Debates, 56.

${ }^{36}$ The New Hampshire convention, in session the latter part of May, had to be adjourned for nearly one month, till June, I788, in order to prevent a defeat for the Constitution. 
chusetts, and perhaps Maryland, and the United States of America would never have been a nation. Instead then of being a mere compromise, fitted to bridge a sectional disagreement, it was a permanent, solemn compact, which perhaps alone made this nation a reality. ${ }^{37}$

The six States named above, together with North Carolina, all adopted a set of amendments which were submitted to the Congress with the prayer that they should be made a part of the Constitution. ${ }^{38}$ Among these amendments was one which declared in substance that the Congress shall not lay direct taxes, but when the money arising from the impost and excise shall be insufficient for the public exigencies, nor even then until Congress shall have first made a requisition upon the States, etc. ${ }^{39}$ This was subscribed to by each one of the seven States which we have named, forming a clear majority of the thirteen colonies. Such was the temper and feeling of the people then, and does anyone really suppose, in the face of these events, that, had the Constitution conceded to the general government an absolute and unlimited power to impose direct taxes, it would ever have been adopted?

It is argued that the framers intended to give this nation unlimited powers of taxation similar to those enjoyed by other sovereign governments. To assert this is to fail to comprehend the genius of American institutions. There is not a word in any of the pages of Elliot's Debates which gives countenance to the idea that the founders either thought they were giving, or intended to give, unlimited powers of taxation to the new nation.

This feature is well summed up in Mr. Justice Field's concurring opinion in Pollock v. Farmers' Loan and Trust Co., where he says:

"There is no such thing in the theory of our national government as unlimited power of taxation in Congress. There are limitations of its powers arising out of the essential nature of all

${ }^{37}$ There is a story that George Washington, when he was about to sign the Constitution, said these words: "Should the States reject this excellent Constitution, the probability is that an opportunity will never again offer to cancel another in peace-the next will be drawn in blood." See Curtis' History of the Constitution (1858), Vol. II, 487, note.

38 These propositions became the basis of the first ten amendments, which were adopted in I79I, and form for us a national bill of rights.

30 This amendment was not adopted by Congress, and fortunately, too. It would scarcely have been proper to take away the direct taxing power entirely from the general government, perhaps placing the latter at the mercy of the States in the matter of requisitions. 
free governments. There are reservations and individual rights, without which society could not exist, and which are respected by every government. The right of taxation is subject to these limitations." 40

Let us compare also Mr. Justice Miller's celebrated words in Loan Association v. Topeka." 41

"It must be conceded that there are rights in every free government beyond the control of the State. A government which recognized no such rights, which held the lives, liberty and property of its citizens, subject at all times to the disposition and unlimited control of even the most democratic depository of power, is after all a despotism. It is true that it is a despotism of the many-of the majority, if you chose to call it so-but it is none the less a despotism."

It was in part to give expression to these basic principles of civilized government, to protect these fundamental rights of persons and property, that the rule of apportionment was inserted in the Constitution. How futile and improper, therefore, is it to argue, that, because other nations impose the income tax, we can do the same. We should carefully consider the conditions which obtain in this country before we conclude, on mere economic theories alone, as the political economists do, that the United States can adopt the income tax.

This country has an area of over three and one-half millions of square miles. Its population is very unequally distributed; its resources and industries are greatly diversified; the standards of living and conditions of wealth of its people are very different and unequal in different sections of the country, ${ }^{42}$ and at the same time, all the more intimate and personal functions of government are reserved to, and exercised by, its forty-eight sovereign States. $^{43}$ Under such circumstances to reason, therefore, that the central government can impose direct taxes with no restraints whatever is to disregard utterly our political institutions, and our

${ }^{40}$ I57 U. S., 429, 599. Compare Mr. Justice Bradley's opinion in Boyd z. U.S., II6 U. S., 616, 630 and 63 I.

4120 Wall., 655, 665.

42 The vast difference in the areas of the territory covered by the government of the United States, and those of European nations, will at once illustrate how impossible are comparisons between the two. For instance, Austria, the largest country territorially, which imposes a national income tax, is but one-fifteenth the size of the United States.

43 No countries in Europe which have anything approaching a federal form of government impose a national income tax. In Switzerland, the income tax is imposed by the separate Cantons, not by the general government. In the German Empire, Prussia and other principalities employ an income tax, but not the imperial government. 
territorial and financial conditions. Now, it will be seen that the income tax being classed as a direct tax, it follows that it cannot fall within the rule of uniformity, which applies only to imposts, duties and excises, while the proposed amendment withdraws it from the rule of apportionment. The income tax will be, therefore, the only kind of imposition known to our Constitution, which can be levied without any restraints whatever. A graduated and progressive income tax, discriminating even to the utmost degree, will be possible under our Constitution, as it shall stand after the adoption of the proposed amendment. ${ }^{44}$ The limit of its exemption can be so artfully framed and the rate of its assessment made so high as to fall exclusively on certain States or sections of the country, or on certain persons, to the exclusion of others, and to the exclusion of the very States and persons through whose votes in Congress perhaps the tax has been imposed.

In times when political feelings and prejudices run high, it will be an instrument of power in the hands of a majority almost certain to be abused. In this country the unbounded power to impose any form of income taxes would give opportunity for free play to all sectional prejudices and open a wide door to invidious class legislation. No authority granted to our government in respect to taxation carries with it such serious dangers of flagrant wrong and injustice, even of oppression, as the unrestrained exercise of the income taxing power.

The rule of apportionment as prescribed in the Constitution to-day has been very severely criticised by some of our jurists and political economists, and the provision has been condemned as having no rightful place in the code of our organic law. Prominent among those who take this position are Professor Charles J. Bullock and Justices White and Harlan, of the Supreme Court. ${ }^{45}$ Notwithstanding some of the vehement denuncia-

44 I am of the opinion that the principle of equality in taxation, and perhaps also the constitutional guarantee of equal protection of the laws, would forbid Congress imposing an income tax within certain States and none whatever in other States. But exactly the same disastrous results may be accomplished by means of a graded and progressive income tax.

${ }_{45} \mathrm{Mr}$. Justice White in his dissenting opinion in the Pollock case condemns the rule of apportionment according to population as the "most flagrantly unjust, unequal and wrongful system of taxation known to any civilized government." Pollock v. Farmers' Loan \& Trust Co., I58 U. S., 565. The words of the learned Justice are altogether immoderate and are not borne out in any way by the facts. As we shall see later, his narrow definition of direct taxes is without justice or common sense. 
tions, it is perfectly true that at the time this qualification was adopted the rule of apportionment, according to population, was as equitable and fair a rule as could have been devised. At the time of the constitutional convention the population of each State was a fair measure of its wealth. Even to-day the better opinion among students of our political institutions is that, while population is no longer an exact index of a State's wealth, an income tax levied under the present rule of apportionment would operate with far greater justice and equity, taking the country as a whole, than one imposed with no qualifications or restraints. Thus, the group of States corresponding to the thirteen original colonies having to-day thirty-eight per cent of the total population of the country, therefore bearing $38 \%$ of the direct taxes of the government, hold $40 \%$ of the country's wealth. This would not be a disproportionate contribution to the burden of the general government.

The writer, however, does not wish to be understood as necessarily defending the rule of apportionment according to population as the only, and most just, method of restriction. Perhaps there should be some other method devised for restraining the general government in its exercise of the direct taxing power. If economic conditions have so changed as to render the operation of the rule inequitable to-day, any amendment of the Constitution ought to be so made as to apply to direct taxes generally. But that is not what the advocates of this amendment propose. They have no intention of modifying the constitutional rule qualifying the exercise of the direct taxing power as a whole and which they so strongly denounce. Rather would they create a new power-the absolute and unlimited authority to tax incomes from whatever source derived, regardless of any restraint whatever, not even the rule of uniformity, a power which we have shown to be unfitted to our scheme of government.

At the time of the adoption of the Constitution experience had shown that of all forms of direct taxes, that against real estate was the one which operated with greatest injustice. It had been proved in the days of the Confederation that tax requisitons apportioned among the States on their real property 
were the most inefficient and most inequitable impositions. Here, it seems to the writer, is the serious weakness in the dissenting opinions of the minority justices in the Pollock case. Their construction of the direct tax clause would leave but two forms of taxation subject to its operation-the tax on land and capitation taxes; and of all direct taxes none is so "flagrantly unjust, unequal and wrongful" (to use Mr. Justice White's language) as the apportioned tax on real estate..$^{40}$ At the same time it is well known that probably not a single member of the Constitutional Convention ever entertained the idea that the federal government which they were forming would ever impose a capitation tax apportioned among the States. Even Mr. Hamilton, who was in favor of giving the broadest powers to the general government, expresses himself as strongly opposed to a capitation tax so far as the general government is concerned. ${ }^{47}$ If we were to adopt the interpretation of the direct tax clause to correspond with the minority opinion in the Pollock case, it would be to impute to those wise statesmen such a want of a sense of justice, and such a political short-sightedness as would be shocking. Much better had they inserted in the Constitution an absolute prohibition against the imposition of direct taxes, and this they would' have done, had their definition corresponded with that of some of our jurists and political economists to-day. But since everything goes to show that the framers expected that the government might be obliged to resort to some form of direct tax in times of national exigency, it is quite conclusive that they interpreted the term "direct taxes" in a much broader way than has been recently contended for. Similarly also to do away with the alleged injustice of this clause by withdrawing from

46 In the debate on the adoption of the Constitution in the Virginia convention, delegates, while objecting to the unqualified exercise of the direct taxing power, criticised the clause in question as being unjust. Madison then defended the constitutional provision on the ground that other objects than real estate were to be included in the term "direct taxes," and that the government could exercise some discretion as to the property on which a direct tax would be imposed. III Elliot's Debates, pp. $254,255$.

17 Hamilton said: "As to poll taxes, I, without scruple, confess my disapprobation of them; I should lament to see them introduced into practice under the national government. But does it follow, because there is a power to lay them, that they will actually be laid?" The Federalist, No. XXXVI. See also II Elliot, 43, 105, 106, 135, 340, 39I and 502. 
its operation the only form of tax that can be apportioned with a fair degree of equity among the States, and to leave within its purview those forms of direct taxes to which the federal government will never resort, seems really absurd, and not in keeping with the dignity of our Constitution:

THE QUESTION OF NECESSITY AND PAST EXPERIENCE.

It is claimed that the general government should be given undoubted power to impose an income tax, regardless of the rule of apportionment, in order that it may be in a position to provide for unseen national exigencies. Any intention of exercising such a power at present is disclaimed, but it may become necessary in some future crisis, so its advocates say. This attempt to amend our Constitution to provide for future necessities as if our forefathers had never known such exigencies and had not made substantial provision for them, would seem to show either great ignorance or presumption.

It was a national exigency which gave birth to the Constitution as we have it to-day. For eight years not long prior to the assembling of the constitutional convention the Congress of the Confederation had been attempting to wage a long and serious war without money, without resources and without power to levy or collect taxes. Briefly, this was the crisis through which those statesmen had passed, and it is probable that in adopting the provisions of the Constitution relating to the taxing powers of the government, their own experience held before their minds the necessity of providing for national exigencies, in a clearer yet more serious aspect than we can view it now. The resources of the country are richer and more varied than ever before, and we are surrounded with an unparalleled internal commerce and our opportunities for industrial activity, even though war might temporarily suspend our foreign trade, are unequal. The whole range of excise taxes on all the varied business activities of this wonderful country lie within the power of the general government and our resources for a national revenue are more extensive and reliable than ever before. ${ }^{48}$ In the face of these considerations, is it not presumptuous for us, on the plea of providing for the future, thus light-heartedly and hastily to amend the Constitution

${ }^{48}$ See Former-Senator George F. Edmunds' article in The Forum (1895), Vol. XIX, 513,517, entitled "Salutary Results of the Income Tax Decision." 
which the nation's founders had drawn up after having survived a financial exigency which it is difficult for us to appreciate?

This country has now had a national existence of one hundred and twenty years. It has endured through peace and war, has confronted many financial crises and internal disturbances, and yet with but one exception, the income tax has never formed an important part of our fiscal policy; and never has it proved to be a vital or really necessary source of national revenue. The exigencies presented at the outbreak of the Civil War were of a different character. The country had just passed through a remarkable period of material prosperity; from 1838 until practically the time when the war broke out, trade and industry were at a high-water mark. The great majority of the people of the country were highly prosperous and wealth was very equitably distributed. During this period the revenue of the government, which was more than ample, was practically derived from duties on imports. From the material point of view this condition of affairs placed the government in a rather favorable position, but in other respects circumstances had brought about a state of mind in which the government had given little thought to the problem of raising extraordinary revenues for a national crisis, and extreme measures had to be resorted to.

It was under these circumstances that the Secretary of the Treasury, Mr. Chase, apologetically suggested an income tax, but scarcely recommended it. ${ }^{49}$ Congress approached the subject with hesitation and it was not until July, I862, that the first income tax became a law, ${ }^{50}$ while the government did not begin to receive

49 In his annual report to Congress, 186r, the Secretary of the Treasury said: "The Secretary is acquainted with no statistics which afford the means of a satisfactory estimate of the amount likely to be realized from the income tax. Considering, however, how large a proportion of income after the deductions sanctioned by law will fall within the exemption limit of $\$ 800$ a year, and considering also what numerous questions will certainly perplex its assessment and collection, he respectfully submits whether the probable revenue affords a sufficient reason for putting in operation, at great cost, the machinery of the act, with a view, should the States assume the direct tax, to the collection of the income tax alone."

50 As a matter of fact, the revenue measure of I86I contained a tax of $3 \%$ on all incomes over $\$ 800$, but the government refrained from levying this tax or enforcing the law. Even in that crisis, Secretary of the Treasury Chase was reluctant to enforce what seemed so radical a form of taxation. 
any revenue therefrom until nearly the middle of 1863 , when " the war itself was half over. This brief reference to its enactment will show us that as an emergency measure the importance of the tax has been greatly exaggerated.

The law of 1862 provided for an imposition of $3 \%$ on all incomes between $\$ 600$ and $\$ 10,000$ and $5 \%$ on all incomes over $\$ 10,000$. The measure of 1865 was made more severe, being $5 \%$ on all incomes of $\$ 600$ and over, 10\% on $\$ 10,000$ and over. Then, too, in addition to the regular revenue measures by an act passed July 4, I864, Congress imposed a special income tax of $5 \%$ on all incomes over $\$ 600$ earned or accrued for the year 1863 .

As a measure to respond immediately to the financial exigencies of the country or to save a nation's credit, the income tax amounted to little or nothing. Estimating the total cost of the war, which was over by the close of the fiscal year $186_{5}$, at $\$ 2,500,000,000$, the income tax from all sources and under laws passed during the war itself yielded only a little over $\$ 86,000,000$, including the special income tax passed in 1864 , but not collected until 1865 . This is only $3 \%$ of the financial burden of that great struggle. The collection of an income tax had to remain in force for more than eight years after peace was concluded to bring the yield up to even as much as one-ninth of the cost. While the income tax furnished in actual figures a substantial sum, it is scarcely accurate to speak of it as having provided a great part of the means for carrying on the Civil War.

In three of the years during the income tax period the yield was substantial, though at no time did it bear a really large proportion to the total revenue. Thus, in I864, the first full year in which the general tax on personal incomes was collected, the receipts from that source alone amounted to but $\$ 14,933,362$, while the total receipts from the internal revenue amounted to $\$ 1$ I7,145,748 , the income tax collections being a little more than onetenth of the revenue; meanwhile, the expenses of the government were running at the rate of something like $\$ 60,000,000$ a month, or considerably over $\$ 700,000,000$ a year. It will be seen that in that year the income tax returned only about one-fiftieth of the total fiscal obligations of the government. In 1866, with the rate at $5 \%$ on all incomes over $\$ 600$ and 10\% on $\$ 10,000$, the direct income tax returned about sixty-eight millions, while the total receipts from internal revenue were $\$ 3$ I0,000,000, of which the income tax yielded $22 \%$. That year marked the tax's culmina- 
tion, for the necessity for such extraordinary revenue being removed, the people were no longer so conscientious in making a return of their taxable incomes and from that time the receipts from this source fell off, at first gradually and then rapidly, until finally in 1872 but a little over eight millions of dollars were received from the income tax out of a total internal revenue of $\$ 132,000,000$, a little more than one-twentieth.

In judging of the efficacy of this tax regard must be had to the very low exemption limit and the very high rate of taxation which prevailed throughout a great part of that period; while patriotism and the war spirit played a great part in furthering honesty in the return of taxable incomes and in the collection of the tax itself. The material condition of our people and the fact that many incomes derived from business pursuits were very largely increased, due to the high price which the necessaries of life and all commodities commanded during the war period, should have largely augmented the returns from this source of revenue. In brief, then, the Civil War period presented extremely favorable circumstances for a successful collection of an income tax, and it is very doubtful whether this country, even in event of the crisis of another war, can again find such a combination of circumstances as will assure even the limited success which we experienced then. ${ }^{51}$

Manifestly, therefore, it is quite misleading to refer to the success and efficiency of the income tax in such exaggerated terms as used by the advocates of the proposed amendment. To speak of the income tax as an important feature of the internal revenue measures of that particular period is proper, but to speak of it as having "once been vital to the preservation of national existence" is very wide of the truth. ${ }^{52}$ The revenue resources of the federal

$51 \mathrm{Mr}$. Joseph A. Hill says: "But it is certain that better results were secured from the tax, and with less complaint and opposition than would be possible in ordinary times. It would have been strange, indeed, if the patriotism which led men to volunteer for the field in such numbers had been inoperative when contributions of money were called for." In "The Civil War Income Tax," Quar. Jour. of Econ., Vol. VIII, pp. 4I6, 45I.

s2 See Senator Root's open letter to Hon. F. M. Davenport, member of the New York State Senate, published in the Congressional Record, March I, I9ro, Vol, 45, p. 2564. It is doubtful whether the able Senator from New York is as ignorant of the facts as he would lead us to believe, and his remarks must rather be regarded as a fine specimen of fervid oratory. 
government and subsequent history have since proved that the income tax of the Civil War, while it was allowed to play an important part, was neither vital nor necessary to national existence. On the whole, then, we must conclude that there is really no financial necessity to warrant this amendment to the United States Constitution, and to refer to its rejection as amounting to "a national calamity" appears to us as culpably misleading. ${ }^{53}$

DIRECT TAXES BY APPORTIONMENT AND THE INCOME TAX COMPARED.

Furthermore, it is probable that an income tax imposed by the general government, after the adoption of the proposed amendment, without regard to any census or enumeration will prove no more efficient or satisfactory as a revenue measure than one levied under the present rule of apportionment. It is believed that experience will show that the rule of apportionment in no way militates against the collection of the tax. In either case the assessment is made against the citizen individually, and the government is at liberty to resort to the same means or processes in collecting the tax whether first levied with or without regard to the rule of apportionment, the only difference being that under the rule of apportionment the quota which it is proposed to collect from each State is first estimated, and to meet this quota the tax is collected from the incomes of the citizens.

The government has never imposed an income tax under the rule of apportionment as now provided by the Constitution. It is, therefore, difficult to judge how satisfactory or effective such a revenue measure would be. What has been said above in this article and the examples which I have given are enough to show that in all probability an income tax levied by apportionment among the several States would yield as large a revenue and be even more equitable in its incidence than the imposition of an unapportioned tax. The comparison between an apportioned income tax and the old direct taxes, to which the government has resorted five times in its history, furnishes a very poor basis by which to judge results. The old direct tax as illustrated by the revenue measures of $1798,1813,1814$ and 1816 was imposed upon "lands, houses and slaves." The provisions in regard to its collection were most awkward and the form of this tax, laid upon

${ }^{3}$ See message of Governor Fort to the New Jersey Legislature of February 7, I9ro. 
real property, was one which, in respect of the objects of its imposition, had proved in the old days of the Confederacy to be impracticable and unjust and had been afterwards abandoned. The government experienced very indifferent success in the collection of this tax. The direct tax of I86I followed in a general way all previous measures of the same nature and the amount which the government set out to obtain from this source was strangely enough put at the very low figure of $\$ 20,000,000$. The peculiar circumstances of the Civil War period and the insurrection of eleven of the Southern States, against each of which was assessed its proper proportion, gave rise to extraordinary difficulties and inequalities; and the direct tax of $186 \mathrm{I}$ proved even more unsatisfactory than previous measures of its kind. In fact, it is quite commonly said that the direct tax as illustrated by the revenue measure of I86x has been completely discredited, but as we have above shown, this was not due to the rule of apportionment so much as it was to that particular tax, the objects of the imposition, ${ }^{54}$ the indifference on the part of the government to this method of raising revenue and the extraordinary circumstances which then prevailed. Even under these conditions. Prof. Charles F. Dunbar, himself a severe critic of the old direct tax, writing in 1888 , says :

"The default in its collection being a default less than oneseventh of the total amount called for, it is probable that this tax has been more completely collected than most of those laid during the war. For example, it has probably been collected more thoroughly than the income tax, the foundation of which was laid by the same act which established the direct tax." :5

In this connection the decision of the Supreme Court in United States $v$. Louisiana ${ }^{58}$ is very interesting. This lecision placed the unpaid quotas of the direct tax of $186 \mathrm{r}$, so far as the processes of its collection are concerned, in precisely the same position as

54 It is noticeable that when the revenue measure was under debate in I86I, Congress objected to the direct tax, not because it was to be imposed under the rule of apportionment, but because it fell upon the owners of real estate only, to the exclusion of all other property holders, particularly share holders and bond holders of corporations. See debates of the 39th Congress in the Congressional Globe, July, r86r. This objection, and a serious one it is, could not be made against an income tax imposed under the rule of apportionment.

${ }^{5}$ See article, "The Direct Tax of I86r," by Chas. F. Dunbar, Quarterly Journal of Economics, Vol. III, pp 436, 452.

se I23 U. S., 32. 
any other tax, including an income tax, assessed upon individuals and which the government would be unable to collect in full. Professor Dunbar says of the direct tax:

"It is difficult, for example, to distinguish it in any essential particular from the case of unpaid income taxes laid during the war and collected by severe proccss through the loyal States, but neither then nor at any other time collected in the insurrectionary States."

FEDERAL TAXATION OF STATE SECURITIES.

Among the serious questions which have been brought out through the proposal to give to the general government power to tax incomes, from whatever source derived without regard to any apportionment, is the question whether this amendment will give to Congress the right to impose a tax on incomes derived from State or municipal securities. Governor Hughes, of New York, with very good reason, is of the opinion that such a rule would make taxation of State and municipal securities possible, and, therefore, perhaps paralyze the proper instrumentalities of State government. Senator Root, of New York, in an open letter to a member of the New York State Senate plausibly argues from exactly the opposite side.

Briefly, the situation seems to be somewhat like this: Under the Constitution as it stands to-day the general government has power to lay and collect taxes, duties, imposts and excises. Of this enumeration, the last three are subject to the rule of uniformity, while the word "taxes" refers to direct taxes alone, which are subject to the rule of apportionment. In general, the taxing clauses of the Constitution give the federal government power to tax any and all kinds of property or business, and all persons within its jurisdiction; at the same time there is no particular species or form of property over which the taxing power of the general government extends any more exclusively than over any other class. It is a general taking power which is hereby given to the government commensurate with its own needs and with the nature of its institutions, and, like any other authority found anywhere in the Constitution, is subject, of course, to the implied limitations which are to be drawn from that Constitution, and which must necessarily inhere as the instrument stands to-day. The Constitution of the United States presupposes two governments existing side by side, one of the individual States and the other of the United States, each of which has its own 
field of jurisdiction and powers of taxation, and, in its own appropriate sphere, is supreme.

It is as true in respect of taxation as it is in other respects, that the government of the United States is now manifestly and intentionally one, not alone of enumerated powers, but of limited powers. It has been erroneously said many times that the taxing power of the government is unlimited, extending to every property, business and person within its jurisdiction, knowing no limitation whatever save the rule of uniformity and that of apportionment, and that these refer, not to the extent of the power itself, but simply to the manner of exercising that power. This is, of course, a contradiction. While the taxing power of the federal government extends to all persons, property and business within its jurisdiction, and to that extent is plenary and complete, even then it is not an unlimited power and was not intended to be such. A qualification effecting the manner of the exercise of a power is necessarily a qualification and limitation of the power itself.

Right here, it seems to the writer, is the error which so many of the advocates of the proposed amendment make. They assert that the taxing power of the federal government is absolute and unfettered, overlooking at the same time that its powers in this particular are not absolute, but are qualified in a most marked and intentional manner by these rules of uniformity and apportionment. In their elaborate arguments to defend their position they fail to notice that the very passages, which they quote from the decisions of the Supreme Court, defining the federal taxing power, are all careful to make specific mention of its actual and implied qualifications. ${ }^{57}$ We are asked to point out the particular provisions of the Constitution which to-day forbid the taxation of State instrumentalities; but it is not in a particular provision that we are to find this inhibition, but by implication it was read into the Constitution by the Supreme Court. Mr. Justice Nelson, of that Court, in Collector v. Day, s8 said: "The exemption rests upon necessary implication." The field of taxation open to the federal government being a general one and not

57 See speech of Senator Borah of Idaho in U. S. Senate, February I4, rgro, Congressional Record, Vol. XLV, p. 1843. But see Mr. Justice Field's language in Pollock v. Farmers' Loan \& Trust Co., I57 U. S., 429, 599; Mr. Justice Miller in Loan Association v. Topeka, 20 Wall., 655. The License Tax Cases, 5 Wall., 462, 47 .

68 iI Wall, II3, I27. 
granted in absolute terms, it necessarily follows that it is qualified by the nature of the instrument itself; and unless there is a specific provision permitting the general government to tax a particular species or form of property so as to include the securities of the States, we must assume that the States in creating the Union never intended that their own instrumentalities should be burdened or taxed. ${ }^{59}$

But, of course, the genius of the Constitution is such that the States may grant to the general government such powers as they please, through the proper channels; and right here under the proposed amendment we meet a clause of very different import. In the form of a grant from the States or the people, this amendment concedes to the general government absolute power to tax a certain form of property. Moreover, it is the only clause in the entire instrument which specifically enumerates a particular form of property, and gives to the general government unlimited power of direct taxation over that property. In the instrument as it is to-day the right to tax incomes is included merely in the general taxing clause, and is possessed by the government only in common with the right to tax every other form of property, and subject to all the expressed and implied qualifications inherent in the Constitution. But in the proposed amendment is an authority conceded in termas so broad and sweeping as are found nowhere else in the instrument, leading us to suppose

so The following illustration may bring out one point at issue. Let us suppose that the general taxing clause of the United States Constitution, instead of reading as it does to-day, read as follows: "The Congress shall have power to lay and collect taxes, duties, imposts and excises upon every form and kind of property whatever and wherever situated." Is there any difference in meaning between such a clause and the one which we have now? Under such a grant would the federal government have the power to tax the. instrumentalities of the States? I apprehend that there is a very marked difference. Under such a constitutional grant I cannot see how the Supreme Court would have been warranted in reading into the Constitution the implied exemption in favor of State instrumentalities as it did in Collector $v$. Day. This is virtually the hypothetical question which Senator Borah of Idaho put in his argument in favor of the proposed amendment at the New York Economic Club debate, March 24, 1910. If the English language is to have any meaning at all, I am of the opinion that the Senator's question must be answered in the affirmative, for there is a decided difference between the clause as it stands now and as it would read under the Senator's hypothesis. 
that any implied exemptions are overruled by the express language in which it is granted. It says:

"Congress shall have power to lay and collect taxes on incomes from whatever source derived, without apportionment among the several States, or without regard to any census or enumeration."

Manifestly, therefore, under this clause taken by itself, the federal government can tax any species of income from any source whatever, including income from all State and municipal bonds and securities, and freed, too, of the rule of uniformity, the power may be exercised in an almost arbitrary manner. The mere fact that the State securities themselves cannot be taxed by the general government will not save us, for this provision separates "income" from the property which produces it. "Income" is put in a class by itself. Just as the rentals from houses and lands will no longer follow real property, and the income from personal estates will no longer follow personal property, here also the income derived from State and municipal bonds is no longer subject to the rules which effect the taxation of such bonds. Prior to the income tax decision in the Pollock case and in the absence of definite adjudication, there was not the same unanimity as to the exemption from taxation of income derived from State securities, as there was respecting the exemption from taxation of such securities themselves. There is, therefore, a strong probability that under this new article no exemption would be allowed in favor of the income derived from State securities simply because such securities themselves would be exempt from tax impositions. ${ }^{60}$ It is a fair presumption from the terms of this grant that this amendment is intended to give to the federal government a taxing power co-extensive with the language used, and corresponding to the unqualified and sweeping nature of its provisions,

${ }^{60}$ But the better judicial opinion was inclined to the rule that the implied exemption in favor of State instrumentalities, eo momine, from federal taxation, carried with it a like exemption of income derived from such instrumentalities. But no less an authority than Mr. Justice Bradley dissented from the opinion of the Court in Collector v. Day, II Wall., II3, 128; and in Weston v. City of Charleston, 2 Peters, 449, 470 and 473. Justices Johnson and Thompson dissented on this express point, that, while there was an implied exemption from State taxation in favor of United States government bonds, the same exemption did not extend to income derived from such bonds, and the tax imposed in that case was in their judgment an income tax. See $M c C$ ulloch $v$. Maryland, 4 Wheat., 3I6; Dobbins v. Erie County, I6 Peters, 435. 
and that, in respect of its authority to tax incomes at least, the federal government is not to be restrained by those implied limitations which qualify the exercise of all other powers granted to it.

It would seem as if the Supreme Court in construing the United States Constituion as it shall be after the adoption of the proposed amendment, will find itself in the midst of inconsistent and contradictory provisions which cannot be construed in harmony with each other. It will be presented with contradictory alternatives, one of which it will have to adopt. Fortunate, indeed, will be this country if the Supreme Court, under these circumstances, shall boldly override the unqualified language of the proposed amendment and exclude from its operations an income tax levied on the instrumentalities of the States. Yet to do this will be a violent stretch of its judicial authority. But what are we to say of an instrument whose provisions and grants are so inharmonious and inconsistent that the Supreme Court cannot construe one part thereof without contradicting and doing violence to the other, nor can it uphold the other without boldly overriding and nullifying the first?

Constitutional, indeed, the imposition of an income tax will be, yet, nevertheless, this amendment is inherently improper under the limitations which ought to guard the concessions of authority to our federal government. In that matchless code, called by one of England's greatest statesmen "the most wonderful work ever struck off at a given time by the brain of man," this amendment will be an anomaly. In an otherwise harmonious instrument which speaks of a government of enumerated powers, seeking to preserve the dignity and vitality of sovereign States, this provision will stand out as the one discordant note, inconsistent with all that has gone before, unexplained, uncalled for, unnecessary, the only grant to the federal government of unrestrained and arbitrary power in respect of taxation over every State and every citizen within those States.

New Haven, Conn. Arthur C. Graves. 